Volume 1, No. 1, April 2021

\title{
POLITIK HUKUM HIERARKI PERATURAN PERUNDANG-UNDANGAN INDONESIA
}

\author{
Fathorrahman \\ Program Studi Hukum Fakultas Ilmu Sosial dan Humaniora \\ Universitas Ibrahimy Situbondo \\ Email: aryawiraraja.45@gmail.com
}

\begin{abstract}
Abstrak
Pengaturan hukum terkait hirarki peraturan perundang-undangan di Indonesia masih terbatas pada jenis dan bentuk tertentu dan hirarki peraturannya berdaasar pada jenis dan bentuknya. Selain berdaasar pada jenis dan bentuk, tidak semua jenis dan bentuk peraturan yang ada, diatur statusnya dalam hirarki sebab pengaturannya masih terbatas pada jenis-jenis tertentu saja yang diatur dalam pasal 7 UU 12/2011. Jenis peraturan yang lain yang diakui entitasnya belum diatur sehingga potensial menjadi problem hukum dari masa ke masa. Jika melihat dari berbagai negara : seperti Jerman dan Belanda, hirarki keduanya, dalam hal ini hirarki peraturan perundang-undangan mengikuti hirarki struktur pemerintahan yang ada tanpa melakukan pengaturan hirarki berdasarkan jenis dan bentuknya. Akan tetapi, Hirarki dari peraturan tersebut mengikuti hirarki otoritas yang mengeluarkan atatu menerbitkan peraturan. Dengan begitu, memudahkan kita semua untuk melakukan pelacakan di mana possisi sebuah peraturan perundangan-undangan. Temuan tersebut tersaji karena dalam penelitian ini, pendekatan yang digunakan adalah pendekatan studi komparasi sistem hirarki antara sistem hirarki Indonesia dengan kedua negara tersebut. Selain juga, melakaukan pendekatan yang bersifat historis. Dengan begitu, politik hirarki ke depan bisa memperhatikan persoalan di atas, sehingga dalam melakukan politik hukum : memasukan atau mengatur semua jenis dan bentuk peraturan yang ada atau hirarki peraturan berdasarkan pada hirarki struktur pemerintahan.
\end{abstract}

Kata Kunci : Politik Hukum, Hirarki, dan Peraturan Perundang-Undangan.

\begin{abstract}
Legal arrangements related to the hierarchy of laws and regulations in Indonesia are still limited to certain types and forms and the regulatory hierarchy is based on the type and form. Apart from being based on type and form, not all types and forms of existing regulations are regulated in a hierarchy because the regulation is still limited to certain types as regulated in Article 7 of Law 12/2011. Other types of regulations that are recognized by the entity have not been regulated so that they have the potential to become legal problems from time to time. If you
\end{abstract}


look at various countries: such as Germany and the Netherlands, the hierarchy is both, in this case the hierarchy of laws and regulations follows the existing hierarchy of government structures without making hierarchical arrangements based on type and form. However, the hierarchy of these regulations follows the hierarchy of the authority issuing or issuing regulations. That way, it makes it easier for all of us to track where the position of a statutory regulation is. These findings are presented because in this study, the approach used is a comparative study approach to the hierarchical system between Indonesia's hierarchical system and the two countries. Apart from that, taking a historical approach. That way, hierarchical politics in the future can pay attention to the problems above, so that in carrying out legal politics: entering or regulating all types and forms of existing regulations or hierarchical regulations based on the hierarchy of government structures.

Keywords: Legal Politics, Hierarchy, and Legislation.

\section{PENDAHULUAN}

\section{A. Latar Belakang}

Toeri Hans Kelsen mengenai jenjang norma atau yang lebih dikenal senagai toeri stufenteori yang menyebutkan bahwa norma-norma hukum berjenjang dan berlapis dalam hirarki. Norma yang uang lebih rendah bersumber dan berdasar pada norma yang lebih tinggi levelnya dalam hirarki sampai pada norma dasar (grungnorm). ${ }^{1}$ Dari gagasan tersebut, dapat disimpulkan bahwa norma-norma atau aturan-aturan yang lebih rendah (inferior) dapat dibentuk oleh norma yang lebih tinggi (superior). Implikasi dari dari toeri tersebut, sejak tahun 1966 sampai hari sekarang, sistem hukum Indonesia juga menganut dan menerapkan toeri jenjang dan lapis di atas.

Bahkan, sudah terjadi beberapa kali perubahan yang bersifat mendasar dari mulai TAP MPRS XX/MPRS/ 1966, TAP MPR NOMOR III/MPR/2000, Undan-Undang Nomor 10 Tahun 2004 dan Undang-Undang Nomor 12 Tahun 2011. Walaupun Undang-Undang yang terakhir sudah mengalami perubahan yakni Undang-Undang Nomor 15 Tahun 2019, akan tetapi perubahan hirarki tersebut tidak mengalami

1 Maria Farida Indrati S, Ilmu Perundang-Undangan I, (Yogyakarta: Penerbit Kanisius, 2007).

74 HUKMY|Jurnal Hukum 
perubahan klasula. Sehingga hirarki peraturan perundang-undanga dalam sistem hukum nasional tetap merujuk kepada Undang-Undang Nomor 12 Tahun 2011.

Pada pasal 7 Undang-Undang No. 12 Tahun 2011 mengatur tentang

- Undang-Undang Dasar NRI 1945

- Ketetapan Majelis Permusyawaratan Rakyat.

- Undang-Undang/Peraturan Pemerintah Pengganti Undang-undang, Peraturan Pemerintah,

- Peraturan Presiden,

- Peraturan Daerah provinsi, dan

- Peraturan Daerah Kabupaten/Kota.

Selain pada pasal 7 Undang-Undang No. 12 Tahun 2012 beberapa jenis dan bentuk peraturan lainnya juga diberi ruang dengan disebutkan di pasal 8 UndangUndang No. 12 Tahun 2011. Akan tetapi, semua jenis yang disebutkan tidak diatur jenjang dan lapisannya, sehingga dapat membingunkan kita semua akan letak dan strukturnya dalam hirarki.

Apakah jenis dan bentuk peraturan perundang-undangan yang disebutkan dalam pasal 8 secara otomastis berada di bawah jenis dan bentuk peraturan yang berada dalam pasal 7 atau terdapat klausul yang lebih khusus yang mengatur persoalan tersebut. Jika membaca secara utuh norma di pasal-pasal dalam UndangUndang No. 12 Tahun 2011 atau bahkan perubahannya, tidak dapat ditemu i aturan khusus yang mengatur perseoalan tersebut.

\section{B. Perumusan Masalah}

Jika kita lihat pada jenis dan bentuk peraturan yang ada pada Pasal 8, maka terdapat beberapa jenis dan bentuk peraturan yang dalam sisi praktek, menunjukan bahwa levelnya jauyh lebih tinggi dari pada jenis dan bentuk peraturan yang di Pasal 7. Taruhlah contoh, Peraturan Menteri yang disebutkan pada Pasal 8 dengan Peraturan Daerah yang disebutkan pada Pasal 7. Dalam prakteknya di lapangan, Peraturan Menteri dapat menerintahkan atau dapat memberi delegasi kepada Peraturan Daerah yang artinya, level dari Perda tersebut lebih rendah dari Peraturan Menteri. 
Jika menggunnakan logika Administrasi Negara, maka secara gampang kita akan menemukan bahwa struktur Kementerian tentu lebih tinggi levelnya dari daripada Pemerintahan daerah. Dari sini kita lihat, apakah hirarki peraturan sesungguhnya adalah mengikuti hirarki srtuktur pemerintahan. Jurnal ini, akan membehasa persoalan tersebut.

\section{Motede Penelitian}

Motede yang digunakan dalam penelitan ini adalah motede Historis dengan melihat beberapa kali sejarah pengaturan hirarki di Indonesia dalam masa ke masa. Syahdan, ditambahi beberapa pendekatan studi perbandingan dari dua negara: sistem hirarki Negara Jerman dan sistem hirarki Negara Belanda.

\section{PEMBAHASAN}

\section{Hirarki Norma Hukum}

Terkait dengan hierarki peraturan perundang-undangan, ada pendapat seorang ahli yang mengatakan bahwa tidak ada sistem di dunia ini yang secara positif mengatur tata urutan peraturan perundang undangan. Kalaupun ada, pengaturannya hanya sebatas pada asas yang menyebutkan misalnya: "Peraturan daerah tidak boleh bertentang dengan dengan peraturan perundang-undangan yang lebih tinggitingkatannya'.atau dalam hal UUD ada ungkapan "the supreme law of theland". ${ }^{2}$ Dari pendapat tadi bahwa kita mendapat gambaran bahwasanya hierarki peraturan perundang-undangan dalam bentuk hierarki jenis seperti yang berlaku di Indonesia secara posiifistik tidak ada. Walaupun memang secara umum peraturan perundang-undangan iu berjenjang dan bertingkat-tingkat.

Menurut Hans Kelsen, norma itu berjenjang berlapis-lapis dalam suatu susunan hierarki. Pengertiannya, norma hukum yang dibawah berlaku, bersumber, dan berdasar dari norma yang lebih tinggi, dan norma lebih tinggi jugabersumber dan berdasar dari norma yang lebih tinggi lagi begitu seterusnya sampaiberhenti pada suatu norma tertinggi yang disebut sebagai Norma Dasar (Grundnorm). Dan masih menurut Hans Kelsen termasuk dalam sistem norma

2 Ni'matul Huda, Negara Hukum Demokrasi dan Judicial Review, Cetakan Pertama (Yogyakarta: UII Press, 2005), hlm. 48. 
yandinamis. Oleh sebab itu, hukum selalu dibentuk dan dihapus oleh lembagalembaga dan otoritas-otoritasnya yang berwenang membentuknya, berdasarkan normayang lebih tinggi, sehingga norma yang lebih rendah (Inferior ) dapatdibentukberdasarkan norma yang lebih tinggi (superior), pada akhirnya hukum menjadiberjenjang-jenjang dan berlapis-lapis membentuk suatu Hierarki. ${ }^{3}$

Dalam membahas masalah struktur norma dan struktur lembaga kita dihadapkan pada teori yang dikemukahkan oleh Benyamin Akzin yang ditulis dalam bukunya dengan judul, Law, state, and International Legal Order.Benyamin Akzin mengemukahkan bahwa pembentukan norma-norma hukum publik itubebrbeda dengan pembentukan norma-norma hukum privat karena apabila kitalihat dari struktur norma ( Norm structure ), maka hukum publik itu berada di atashukum privat, sedangkan apabila dilihaqt dari struktur lembaga (institutionalstructure), maka public authorities terletak pada pada pada population..

Dalam hal pembentukan norma -norma hukum publik itu dibentuk oleh lembaga-lembaga negara (penguasa negara, wakil-wakil rakyat) atau disebut suprastruktur sehingga dalam hal ini terlihat jelas bahwa noorma-norma hukum yang diciptakan oleh lembaga-lembaga negara ini mempunyai kedudukan lebih tinggi daripada norma-norma hukum yang dibentuk oleh masyarakat akan yng disebut Infrastruktur. ${ }^{4}$

Oleh karena Norma hukum publik itu dibentuk oleh lembaga negara, yang mempunyai kedudukan yang lebih tinggi dari hukum privat. Hukum publik mempunyai peranan untuk mengatur masyarakat secara luas sedangkan hukum privat adalah hukum yang lebih bersifat kepentingan-kepentingan masyarakat dalam berinteraksi dengan masyarakat yang lain. Dari penjelasan tersebut dapat kita lihat bahwa hierarki peraturan perundang-undangan juga berlaku pada klasifikasi hukum privat dan hukum publik.

Sebelum lebih jauh membahas terkait dengan hierarki peraturan perundangundangan dalam sistem peraturan perundang-undangan, maka peneliti akan

3 Aziz Syamsuddi, Proses Dan teknik Penyusunan Undang-undang, cetakan pertama ed (Jakarta: Sinar Grafika, 2011), hlm. 14-15.

4 Benyamin Akzin, Law, State and International Legal Order,: essays in Honor kelsen, (Knoxville the University of Tennesee, 1964), hlm. 3-5. 
mencoba menampilkan sejarah perkembangan sistem peraturan perundangundangan yang pernah berlaku dalam sistem hukum kita. Hal ini dilakukan untuk mendapatkan pemahaman yang utuh terkait sistem atau hierarki peraturan perundang-undangan di indonesia. Dus, dengan menampilkan perkembangan heierarki peraturan perundang-undangan maka akan dihasilkan sebuah solusi untuk melakukan perbaikan penataan guna menciptakan sistem atau hierarki peraturan perundang-undangan yang ideal.

\section{Sejarah Hierarki Peraturan Perundang-Undangan}

Sebelum perubahan, UUD NRI 1945 sistem peraturan perundang-undangan tidak ditentukan secara jelas dan eksplisit mengenai sistem perundang-undangan atau tata urut peraturan perundangundangan yang ada di Indonesia. Pada saat itu dikenal beberapa peraturanperundang-undangan yang terdapat di dalam UUD NRI 1945, sebagai berikut:

a) Undang-Undang, produk legislatif Presiden bersama-sama DPR (Pasal 5ayat (1) jo Pasal 20 UUD NRI 1945);

b) Peraturan pemerintah sebagai Pengganti Undang-Undang, yang sederajat dengan Undang-Undang (Pasal 22 UUD NRI 1945); dan

c) Peraturan Pemerintah, yang derajatnya dibawah Undang-Undang (Pasal5 ayat (2) UUD NRI 1945). ${ }^{5}$

Terbentuknya sistem atau tata urutan peraturan perundang-undangan pada saat berakhirnya masa pemerintahan Ordelama dan memasuki pemerintahan masa Orde Baru, pemerintah mengeluarkan Ketetapan Majelis PermusyawaratanRakyat Sementara dengan No.XX/MPRS/1966 tentang Memorandum DPR-GR mengenai Sumber Tertib HukumRepublik Indonesia dan Tata Urutan PeraturanPerundangundangan Republik Indonesia disingkat TAPMPRS No.XX/MPRS/1966. Dalam lampiran II (pokokPikiran IIA) TAP MPRS tersebut disebutkan Bentuk danTata Urutan Peraturan Perundang-undangan RepublikIndonesia menurutUndang-Undang Dasar 1945: 6

5 Ni'matul Huda, Negara Hukum Demokrasi dan Judicial Review, hlm. 2.

6 Natabaya, Sistem Peraturan Perundang-Undangan di Indonesia, (Jakarta: Sekretariat Jenderal dan Kepaniteraan Mahkamah Konstitusi RI, 2006), hlm. 112. 
1. Undang-undang Dasar 1945

2. Ketetapan MPR

3. Undang-undang/ Peraturan PemerintahPengganti Undang-undang

4. Peraturan Pemerintah

5. Keputusan Presiden.

6. Peraturan-peraturan pelaksana lainnya seperti:

a) Peraturan Menteri;

b) Instruksi Menteri;

c) Dan lain-lain-nya

Ketetapan MPRS No.XX/MPRS/1966 mengalami perubahan pada tahhun 2000. Perubahan tersebut terjadi setelah dikeluarkannya ketepatan MPR No III/MPR/2000. Dalam Ketetapan Majelis PermusyawaratanRakyat No III/MPR/2000 menyebutkan tataurutan peraturan perundang-undangan mengalami perubahan, salah satunya adalah menempatkankedudukan Ketetapan Majelis Permusyawaratan Rakyatberada diurutan kedua setelah UUD NRI 1945.Ketetapantersebut merupakan perubahan dari KetetapanMajelis Permusyawaratan Rakyat SementaraNo.XX/MPRS/1966 yang sebelumnya masih terdapat banyak kelemahan dalam upaya membuat hierraki.Adapun tata urutan peraturanperundang-undangan berdasarkan Tap ini adalah:

a) Undang-Undang Dasar 1945;

b) Ketetapan Majelis Permusyawaratan Rakyat Republik Indonesia;

c) Undang-Undang;

d) Peraturan Pemerintah Pengganti Undang-Undang;

e) Peraturan Pemerintah;

f) Keputusan Presiden;

g) Peraturan Daerah.

Dalam ketetapan ini sistem peraturan perundang-undangan sudah mengalami kemajauan yang luar biasa. Kemajuan tersebut dapat dilihat dari susunan tata urutan yang sudah menghapus redaksi lain-lain yang sebelumnya, berdasaarkan Ketetapan MPRS No.XX/MPRS/1966, juga menjadi bagian dari hieraraki peraturan perundang-undangan. 
Dengan dihapusnya redaksi "dan lain-lain"menciptakan kejelasan tentang hierarki secara utuh dan tidak menimbulkan multi tafsir tentang kepada lembagalembaga negara dan pemerintahan. Limitatif terkait hierarki peraturan perundangundangan yang diciptakan oleh ketetapan ini juga mencegah timbulnya peraturanperaturan baru Yang tidak jelas letak tata urutnya dalam sistem peraturan nasional.

Perbaikan yang cukup mendasar dari ketetapan ini juga terletak pada diakomodirnya peraturan daerah sebagai sebuah instrumen yang memberikan kewenangan kepada pemerintah daerah untuk membuat sebuah peraturan perundang-undangan. Walaupun, berbagai kelemahannya adalah peraturanperaturan yang lain seperti Keputusan Menteri, Keputusan Lembaga Non Departemen, Peraturan Daerah dan KeputusanKepala Daerah.

Pada tahun 2004, dikeluarkanperaturan baru yang mengatur tentang tata urutan peraturan perundang-undangan. Peraturan tersebut adalah Undang-Undang RI Nomor 10 Tahun 2004tentang Pembentukan Peraturan Perundang-Undangan untukyang pada dasarnya memenuhi perintah Pasal 22A UUD NRI NRI 1945 dan Pasal 6 Tap MPR No.III/MPR/2000.

Undang-undang ini pada dasarnya dimaksud untuk membentuksuatu ketentuan yang baku mengenai tata cara pembentukan peraturan perundangundangan yang baik di tingkat pusat maupun daerah, dan juga menjadi alat atur secara lengkapdan terpadu baik dari tahap perencanaan yang diatur melalui Program LegislasiNasional dan Program Legislasi Daerah, sistem, asas, jenis dan materi muatanmasing-masing peraturan perundang-undangan, tahap persiapan, pembahasan, pengesahan, pengundangan dan penyebarluasan, maupun partisipasi masyarakat.Adapun jenis peraturan yang terakomodir di dalam UU 10/2004 sebagaimanaditentukan dalam Pasal 7 ayat (1), antara lain:

1. Undang-Undang Dasar Negara Republik Indonesia Tahun 1945;

2. Undang-Undang/Peraturan Pemerintah Pengganti Undang-Undang;

3. Peraturan Pemerintah;

4. Peraturan Presiden;

5. Peraturan Daerah;

6. Peraturan Daerah Provinsi;

7. Peraturan Daerah Kabupaten/Kota;

80 HUKMY|Jurnal Hukum 


\section{Peraturan Desa.}

Di dalamPasal 7 ayat (4) UU 10/2004 juga disebutkan Jenis peraturan perundang-undangan selain dalamketentuan yang terdapat pada ayat (1), antara lain; Peraturan yang dikeluarkan oleh MajelisPermusyawaratan Rakyat dan Dewan Perwakilan Rakyat, Dewan PerwakilanDaerah, Mahkamah Agung, Mahkamah Konstitusi, Badan Pemeriksa Keuangan,Bank Indonesia, Menteri, kepala badan, lembaga, atau komisi yang setingkat yangdibentuk oleh undang-undang atau pemerintah atas perintah undang-undang,Dewan Perwakilan Rakyat Daerah Provinsi, Gubernur, Dewan Perwakilan RakyatDaerah Kabupaten/Kota, Bupati/Walikota, Kepala Desa atau yang setingkat.

\section{Hierarki Peraturan Dalam Sistem Peraturan Perundang-Undangan (UU No. 12/2011)}

Hierarki peraturan perundang-undangan dalam sistem peraturan perundangundangan kita diatur dalam Undang-Undang Nomor 12 Tahun 2011. Undang-undang ini menjadi batu pijak dalam melakukan perencanaan, penyusunan, teknik penyusunan, pembahasan dan pengesahan atau penetapan rancangan peraturan perundang-undangan. Persoalan-persoalan yang juga menjadi penting adalah peraturan tersebut juga memuat materi-materipokok tentang asas; jenis, hierarki, dan materimuatan peraturan perundang-undangan.

Untuk memastikan agar peraturan perundang-undangan dapat mendukungtegaknya prinsip negara hukum makasetidaknya diperlukan dua (2) tertib yaitu tertibdasar peraturan perundang-undangan dantertib pembentukan peraturan perundangundangan. ${ }^{7}$

Ikhwal tentang hierarki peraturan perundang-undangan masuk kedalam salah satu dari kedua tertib yang disampaikan ahli hukum di atas. Ia menjadi salah satu dari tertib dasar peraturan perundang-undangan yang termuat dan diatur dalam UndangUndang 12/2011.

Adapun masalah tertib pembentukan peraturan perundang-undanganadalah penyusunan dan realisasi programperencanaan pembentukan peraturanperundang-

7 Bayu Dwi Anggono, Masalah-Masalah Hukum 1: Tertib Jenis, Hierarki, dan Materi Muatan Peraturan Perundang-Undangan: Permasalahan dan Solusinya, (2018), hlm 1. 
undangan yang kurang rasional,permasalahan dalam proses harmonisasirancangan peraturan perundang- undangan,minimnya ruang partisipasi publik dalampembahasan, dan belum dilembagakannyaevaluasi peraturan perundangundangan. ${ }^{8}$

Pengaturan soal hierarki dalam Undang-Undang 12/2011 berada di dalam Pasal 7. Adapun Jenis dan hierarki peraturan perundang-undangan terdiri atas sebagai berikut :

- Undang-Undang Dasar Negara Republik Indonesia 1945.

- Ketetapan Majelis Permusyawaratan Rakyat.

- Undang-Undang/Peraturan Pemerintah Pengganti Undang-undang, Peraturan Pemerintah,

- Peraturan Presiden,

- Peraturan Daerah provinsi, dan

- Peraturan Daerah Kabupaten/Kota.

Selain jenis yang sudah disebut di dalamPasal (7) di atas juga disebut peraturan perundang-undangan lainnya juga dsebut jenisnya di dalamPasal (8) angka satu (1). Bunyi Pasalnya adalah jenis peraturan perundang-undangan selain sebagaimna dimaksud dalam Pasal 7 ayat (1) mencakup peraturan yang ditetapkan Majelis Permusyawaratan Rakyat, Dewan Perwakilan Rakyat, Dewan Perwakilan Daerah, Mahkamah Agung, Mahkamah Konstitusi, Badan Pemeriksa Keuangan, Komisi Yudisial, Bank Indonesia, Menteri, Badan, Lembaga atau Komisi yang setingkat yang dibentuk dengan Undang-Undang atau Pemerintah atas perintah UndangUndang, Dewan Perwakilan Rakyat Daerah Provinsi, Gubenur, Dewan Perwakilan Rakyat Daerah Kabupaten/Kota, Bupati/Wali Kota, Kepala Desa atau setingkat .

Ketika melihat norma dari beberapa Pasal tersebut maka banyak sekali jenis peraturan perundang-undangan yang diatur dan diakui keberadaannya. Semua jenis peraturan tersebut haruslah taat tertib, baik tertib dasar dan ataupun tertib pembentukan. Salah satu tertib dasar yang menjadi barang wajib adalah berkesesuaian jenis, fungsi dan hiereakinya seperti yang disebutkan dalam Pasal 1

$8 \quad$ Ibid. hlm. 2.

82 HUKMY|Jurnal Hukum 
angka (13)yang berbunyi "Materi Muatan Peraturan Perundang-undangan adalah materi yang dimuat dalam Peraturan Perundang-undangan sesuai dengan jenis, fungsi, dan hierarki Peraturan Perundang-undangan. ${ }^{9}$

Terkait dengan hierarki peraturan kekuatan hukum peraturan perundangundangan itu dijelaskan pada Pasal 7 ayat (2) yang berbunyi kekuatan hukum Peraturan Perundang-undangansesuai dengan hierarki sebagaimana dimaksud padaayat (1). Lebih diperjelas lagi didi dalam penjelasan dengan redaksi dalam ketentuan ini yang dimaksud dengan "hierarki" adalahpenjenjangan setiap jenis Peraturan Perundang-undangan yangdidasarkan pada asas bahwa Peraturan Perundang-undanganyang lebih rendah tidak boleh bertentangan dengan PeraturanPerundang-undangan yang lebih tinggi

Di dalamPasal yang lain juga dijelaskan bahwa pembentukan peraturan perundang-undangan ada asas-asas yang tidak boleh dihilangkan oleh pembuat peraturan. Hal tersebut diatur di dalamPasal (5) yang berbunyi dalam membentuk Peraturan Perundang-undanganharus dilakukan berdasarkan pada asas PembentukanPeraturan Perundang-undangan yang baik, yangmeliputi:

a) kejelasan tujuan;

b) kelembagaan atau pejabat pembentuk yang tepat;

c) kesesuaian antara jenis, hierarki, dan materi muatan;

d) dapat dilaksanakan;

e) kedayagunaan dan kehasilgunaan;

f) kejelasan rumusan; dan

g) keterbukaan

Di dalam penejelasan terkait PasalPasal 5 item (c) tersebut juga disebutkan bahwa "asas kesesuaian antara jenis,hierarki, dan materi muatan" adalah bahwa dalamPembentukan Peraturan Perundang-undangan harus benarbenarmemperhatikanmateri muatan yang tepat sesuaidengan jenis dan hierarkiPeraturan Perundang-undangan.

Sebelum kita kita mendapat gambaran terkait Hierarki peraturan delegasai yang menjadi fokus kajian ini, kita harus melihat terlebih dahulu tentang apa saja

9 Undang-Undang Nomor 12 Tahun 2011 Tentang Pembentukan Peraturan Perundang-Undangan. 
yang termasuk dan menjadi peraturan delegasi. Menurut beberapa teori yang sudah disebut di dalam kajian teori maka kita dapat peraturan hukum yang dibuat oleh parlemen, baik dalam bentuk Undang-Undang (statute atau primary legislation) atau berupa aturan hukum yang dibuat oleh otoritas lain yang mendapat pelimpahan kekuasaan (delegasi) dari parlemen untuk membuat aturan perundang-undangan yang dikenal sebagai subordinate atau secondary legislation, ${ }^{10}$ Atau dalam bahasa lain disebut sebagai sebuah peraturan perundang-undangan yang dibuat oleh otoritas lain yang mendapat pelimpahan kekuasaan (delegasi) dari parlemen. ${ }^{11}$

Lembaga-lembaga yang menetapkan peraturan-peraturan itu (peraturan delegasi) yang pada umumnya adalah lembaga yang berada pada ranah eksekutif yang ia tidaklah berwenang untuk menetapkan apabila tidak mendapat wewenang dari undang-undang, oleh karena itu peraturan ini disebut sebagai Executive Acts" atau peraturan yang ditetapkan oleh lembaga pelaksana undang-undang. ${ }^{12}$

Walaupun pendapat lain juga mengatakan bahwa tidak semua peraturan perundang-undangan yang dibuat selain oleh lembaga legislatif tidak menjadi peraturan delegasi saja. Terdapat 4 sifat atau ciri dari suatuperaturan perundangundangan (wettelijkregeling) yaitu, pertama, berupa keputusantertulis, jadi mempunyai bentuk atau formattertentu.Kedua, dibentuk, ditetapkan, dandikeluarkan oleh pejabat yang berwenang,baik di tingkat pusat maupun tingkat daerahberdasarkan atribusi maupun delegasi. ${ }^{13}$

Melihat dari apa yang diatur dalam pendelegasian wewenang dalam UndangUndang 12/2011, maka dapat diambil sebuah gambaran bahwa peraturan delegasi adalah semua jenis peraturan perundang-undangan yang sudah disebutkan dalam Pasal (7) dan (8), kecuali jenis-jenis peraturan perundang yang berupa UndangUndang Dasar NRI 1945, Ketetapan MPR, dan Undang-Undang/Peraturan Pemerintah Pengganti Undang-Undang.

Problematik yang muncul kemudian adalah terkait letak atau posisi tata urut peraturan delegasi dalam hierarki peraturan. Dalam hierarki yang disebutkan di

10 Aan Efendi \& Freddy Poernomo, Hukum Administrasi, (Jakarta: Sinar Grafika, 2017), hlm 48.

11 Ibid.

12 Jimly Asshiddiqie, Perihal Undang-Undang, (Jakarta: Konstitusi Press, 2009), hlm 275.

13 Bayu Dwi Anggono, Tertib Jenis, Hierarki, dan Materi Muatan Peraturan Perundang-Undangan: Permasalahan dan Solusinya, hlm 3. 
dalam undang-undang hanya terbatas kepada jenis peraturan yang disebut dalam Pasala (7) saja. Peraturan-peraturan yang lain, yang merupakan jenis peraturan perundang-undangan yang disebutkan di dalamPasal (8) tidak diatur hierarki atau tata urutnya.

Bahkan menerut Bayu Dwi Anggono, keberadaan Pasal (8) ini memunculkan masalah mengingatsesuai dengan sifat atau ciri peraturanperundang-undangan maka tidak semua jenisperaturan yang dibentuk oleh lembaga Negaraatau pejabat dapat dikategorikan sebagaiperaturan perundang-undangan. ${ }^{14}$ KeberadaanPasal 8 ayat (1) telah memberikanpemahaman baru bahwa semua peraturanseperti peraturan MPR, peraturan DPR, peraturan DPD, peraturan MA, peraturan MKmasuk kategori peraturan perundangundangan sepanjang diperintahkan olehperaturan perundangundangan yang lebih tinggi atau dibentuk berdasarkan kewenangan, Padahal tidak semua lembagatersebut dapat membentuk peraturan yangmengikat ke luar. ${ }^{15}$ Keberadaan Peraturan Mahkamah Agung danPeraturan Mahkamah Konstitusi seharusnya tidak boleh bersifatperundang-undangan artinya tidak bolehmengikat keluar. ${ }^{16}$

Jika dilihat dari penjelasan Undang-Undang 12/2012 dibagian Bab II Hal-hal Khusus tentang pendelegasian kewenangan dijelaskan bahwa Pendelegasian kewenangan dapat dilakukan dari suatu Undang-Undang kepada Undang-Undang yang lain, dari Peraturan DaerahProvinsi kepada Peraturan Daerah Provinsi yang lain, atau dariPeraturan Daerah Kabupaten/Kota kepada Peraturan Daerah Kabupaten/Kota yang lain. ${ }^{17}$

Secara faktual juga banyak ditemukan ditemukan model-model pendelegasian dari satu peraturan ke peraturan yang lain yang tingkatan sama atau bahkan meloncat dari tata urut peraturan perundang-undangan kita. Belum lagi persoalan benturan norma antara peraturan yang satu dengan peraturan yang lain yang dalam hierarki yang tidak ditentukan tata urutanya.

14 Ibid.

15 Ibid.

16 Ibid.

17 Penjelasan Undang-Undang Nomor 12 Tahun 2011 Tentang Pembentukan Peraturan PerundangUndangan. 
Salah satu contoh model dan bentuk pendelegasian tersebut dapat mengakibatkan kebingungan apabila ditelisik dari sisi hierarkinya. Peraturan manakah yang menjadi validitas keberlakuan peraturan tersebut apabila ia memiliki hierarki yang sama dimata hukum. peraturan yang sama secara hierarki melakukan pendelegasian kepada jenis peraturan yang lain. Hal ini tentu menimbulkan ketidakjelasan rumusan dikarenakan jenis peraturan perundang-undangan kita bertingkat-tingkat. Hal tersebut tergambar dalam Pasal (9) ayat (1) yang berbunyi "Ketentuan mengenai tata cara penentuan ganti kerugian, rehabilitasi dan pembebebanan ganti kerugian diatur dalam undang-undang". 18

Selain hal tersebut, beberapa hal yang juga bisa jadi perhatian adalah terkait jenis peraturan yang mendelegasikan baik dari sisi induk peraturannya dan bentuk peraturan yang mendapat delegasi. Dalam sistem peraturan yang berlaku, hierarki disusun bertingkat-tingkat berdasar jenis dan bentuk dimulai dari Undang-Undang Dasar NRI 1945, Ketetapan MPR, Undang-Undang/peraturan Pemerintah Pengganti Undang-Undang, Peraturan Pemerintah, Peraturan Presiden,Peraturan Daerah Provinsi dan Peraturan Daerah Kabupaten/Kota.

Kalau melihat dari susunan di atas maka dapat disimpulksn bahwa tata urut tersebut beraturan sesuai dengan tata urutannya, tata urut tersebut berlaku dimaulai dari penyebutan pertama sampai kepada jenis peraturan yang lain. Artinnya Peraturan Daerah Kabupaten/Kota berada paling bawah dalam hierarki. Akan tetapi ikhwal tersebut menjadi sulit dimengerti ketika ada peraturan perundang-undangan yang mendelegasikan kepada peraturan yang bukan dibawahnya langsung.

Tidak taat hierarki tersebut bisa dilihat dari banyaknya peraturan perundangundangan yang tidak memerintah jenis peraturan yang berada dibawahnya langsung, sebagai contoh terdapat pada Pasal 14 Undang-Undang No. 23 Tahun 2006 yang berbunyi ketentuan lebih lanjut mengenai persyaratan dan tata cara penerbitan perubahan dokumen pendaftaran penduduk sebagaimana dimaksud ayat (1) diatur dalam peraturan menteri.

Dalam kasus yang lain kita dapat menemukan jenis Peraturan Pemerintah Republik IndonesiaNomor 60 Tahun 2014TentangDana Desa Yang Bersumber Dari

18 Undang-Undang Nomor 48 Tahun 2009 tentang Kekuasaan Kehakiman. 
Anggaran Pendapatan Dan Belanja Negara memerintahkan pengaturan kepada jenis peraturan menteri sebagaimana pada pada Pasal 14 yang berbunyi "ketentuan lebih lanjut mengenai tata cara pengalokasian dana desa diaturdengan peraturan menteri”.

Kalau dilihat dari induk peraturan yang memberi delegasi maka dapat disimpulkan bahwa peraturan delegasi dapat menerima dari semua jenis peraturan yang berada di atasnya. Dengan begitu apakah Undang-Undang sama posisnya secara hierarki dengan Peraturan Pemerintah apabila ia sama-sama memberi delegasi kepada jenis peraturan yang "sama" seperti kasus di atas.

Contoh yang lain yakni dalam Undang-Undang No. 6 Tahun 2014 tentang Desa. Di dalam undang-undang ini bentuk peraturan yang mendapat delegasi berbeda jenisnya. Pada Pasal 40 ayat (4) yang berbunyi "Ketentuan lebih lanjut mengenai pemberhentian KepalaDesa sebagaimana dimaksud pada ayat (1) diatur dalamPeraturan Pemerintah". Pasal 47 ayat (6) juga berbunyi "Ketentuan lebih lanjut mengenai Musyawarah Desasebagaimana dimaksud pada ayat (3) diatur dalamPeraturan Pemerintah".

Pasal yang lain, yakni Pasal 35 ayat (2) mengatakan "Ketentuan lebih lanjut mengenai BadanPermusyawaratan Desa diatur dalam PeraturanDaerah Kabupaten/Kota". ${ }^{19}$ Dari hal tersebut dimanakah posisi antara Peraturan Pemerintah dengan Peraturan daerah Kabupaten/Kota ketika ia mendapat delegasi dari jenis Undang-Undang yang sama.

Kalau kita coba perbandingkan dengan sistem peraturan di Belanda dan German, maka kita dapat melakukan suatu perbaikan sistem peraturan perundangundangan dindonesaia. Menurut A'an Efendi, Problematika seperti ini tidak akan muncul jika mengikuti pola hierarki seperti yang berlaku di Belanda. ${ }^{20}$ Dibelanda hierarki UU dengan UU terjadi antara UU organik dengan UU biasa. UU organik lebih superior dibandingkan UU biasa. Di Indonesia, apakah UU yang memerintahkan

19 Undang-Undang Republik Indonesia No. 6 Tahun 2014 tentang Desa.

20 gresnewscom, "Problematika Hierarki Peraturan Perundang-undangan", online: gresnews.com http://www.gresnews.com/berita/opini/170227-problematika-hierarki-peraturan-perundangundangan. 
Politik Hukum Hierarki Peraturan Perundang-Undangan Indonesia

untuk diatur lebih lanjut dengan UU dapat disebut UU organik dan UU yang diperintahkan itu dapat disebut UU biasa sehingga ada hierarki diantara keduanya. ${ }^{21}$

Di Belanda, hierarki peraturan perundang-undangan terdiri atas: 1 . Constitutional Norms, 2.Iinternational and European law, 3. Parliamentary Acts terdiri atas: a. Organic Acts Of Parliaments, b. Ordinary acts of parliament.Kemudian, 4.Orders In Council, 5.Case Law dan 6.Administrative Rules (Netherlands Council of State, 2013). 22

Perbandingan berikutnya adalah konstitsi di Jerman, di german kedudukan pearturan perundang-undangan berdasar pada hirarki struktur pemerintahan, maka oranisasi yang lebih tinggi mempunyai atau mengeluarkan peraturan perundangundangan yang otomatis mempunyai kedudukan yang lebih dari peraturan yang dikeluarkan oleh organisasi peemerintahn yang lebih rendah.

Maka, produk hukum kekuasaan legislatif pada negara federal meminta diatur lebih lanjut dengan produk hukum negara bagian maka tidak akan menimbulkan persoalan hierarki dengan produk hukum kekuasaan eksekutif pada negara federal karena produk hukum negara bagian selalu berkedudukan lebih rendah. ${ }^{23}$

Kalau melihat Pasal 21 konstitusi mereka, hierarki peraturan perundangundangan di Jerman dan di atur juga dalam Pasal 31 yangmenyatakan bahwa produk hukum negara federal (pemerintah pusatkalau di Indonesia) lebih tinggi kedudukannya dibandingkan denganproduk hukum negara bagian (pemerintah daerah kalau di Indonesia, bisa menyebutnya oraganisasi yang lebih rendah. ${ }^{24}$ Maka kedepan persoalan peraturan perundang-undangan kita dalam soal hirarki harusnya menjadi perhatian yang luar biasa agarr tercipta kondisi hukum yang baik.

\section{KESIMPULAN}

Mengenai hierarki peraturan delegasi dalam sistem peraturan perundangundangan Indonesia adalah masih ada peraturan yang disebutkan dalam Pasal 8

21 Ibid.

22 Netherlands/Council of State, Administrative Jurisdiction Division / 201301173/1 | European Union Agency for Fundamental Rights", online: http://fra.europa.eu/en/caselaw-reference/netherlandscouncil-state-administrative-jurisdiction-division-2013011731

23 gresnewscom, "Problematika Hierarki Peraturan Perundang-undangan"

24 Basic Law for the Federal Republic of Germany, online: <https://www.gesetze-iminternet.de/englisch_gg

88 HUKMY|Jurnal Hukum 
Undang-Undang 12/2011 yang tidak diatur hierarkinya dalam sistem peraturan. Pengaturan hieraki hanya disebutkan dalam Pasal 7 yang masih terbatas pada peraturan tertentu saja. Bahkan dalam sistem hierarki yang diterapkan menimbulkan berbagai macam persoalan karena dikategorikannya beberapa peraturan yang seharusnya tidak masuk sebagai peraturan yang mengikat umum keluar. Bahkan posisi atau tata urutan beberapa peraturan tidak dapat ditentukan dengan pasti.

Maka ke depan, politik hukum yang bisa dilakukan dalam menyusun hirarki peraturan perundang-undangan adalah dengan memasukan semua jenis dan bentuk peraturan yang diakui keberadaannya dalam hirarki. Jika hal tersebut tidak memungkinkan, maka bisa saja kita, hirarki peraturan perundang-undangan berdasar pada hirarki struktur pemerintahan atau negara.

\section{Daftar Pustaka}

Akzin, Benyamin, Law, State and International Legal Order,: essays in Honor kelsen, Knoxville the University of Tennesee, 1964.

Anggono, Bayu Dwi, Tertib Jenis, Hierarki, dan Materi Muatan Peraturan PerundangUndangan: Permasalahan dan Solusinya", Masalah-Masalah Hukum.

Asshiddiqie, Jimly, Perihal Undang-Undang, Jakarta: Konstitusi Press, 2009.

Efendi, Aan \& Freddy Poernomo, Hukum Administrasi, Jakarta: Sinar Grafika, 2017.

gresnewscom, Problematika Hierarki Peraturan Perundang-undangan", online: gresnews.com <http://www.gresnews.com/berita/opini/170227problematika-hierarki-peraturan-perundang-undangan $/>$.

Huda, Ni'matul, Negara Hukum Demokrasi dan Judicial Review, Cetakan Pertama, Yogyakarta: UII Press, 2005.

Indrati S, Maria Farida, Ilmu Perundang-Undangan I, Yogyakarta: Penerbit Kanisius, 2007.

Natabaya, Sistem Peraturan Perundang-Undangan di Indonesia, Jakarta: Sekretariat Jenderal dan Kepaniteraan Mahkamah Konstitusi RI, 2006.

Syamsuddin, Aziz, Proses dan Teknik Penyusunan Undang-Undang, cetakan pertama, Jakarta: Sinar Grafika, 2011. 
Politik Hukum Hierarki Peraturan Perundang-Undangan Indonesia

Netherlands/Council of State, Administrative Jurisdiction Division/201301173/1| European Union Agency for Fundamental Rights, online: <http://fra.europa.eu/en/caselaw-reference/netherlands-council-stateadministrative-jurisdiction-division-2013011731>.

Basic Law for the Federal Republic of Germany, online: <https://www.gesetze-iminternet.de/englisch_gg/>.

Undang-Undang Nomor 12 Tahun 2011 Tentang Pembentukan Peraturan PerundangUndangan.

Undang-Undang Nomor 48 Tahun 2009 tentang Kekuasaan Kehakiman.

Undang-Undang Republik Indonesia No. 6 Tahun 2014 tentang Desa. 